\title{
Groundwater Quality in the Rio Grande Aquifer System, Southwestern United States
}

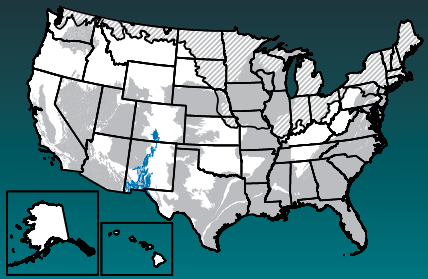

Groundwater provides nearly $\mathbf{5 0}$ percent of the Nation's drinking water. To help protect this vital resource, the U.S. Geological Survey (USGS) National Water-Quality Assessment (NAWQA) Project assesses groundwater quality in aquifers that are important sources of drinking water. The Rio Grande aquifer system constitutes one of the important aquifers being evaluated.

\section{Background}

The Rio Grande aquifer system underlies an area of 29,000 square miles in Colorado, New Mexico, and Texas. The aquifer system is an important source of groundwater for public supply, ranking 18th in the Nation for this use and providing about 240 million gallons per day (Arnold and others, 2017a). The aquifer system is also used for domestic supply (ranked 17th for this use at about 18 million gallons per day) and irrigation (ranked 11th for this use at about 867 million gallons per day; Arnold and others, 2017a). Land use overlying the aquifer system is mostly undeveloped (93 percent) with small amounts of agricultural ( 4 percent) or urban ( 3 percent) land. The overlying land area has a population of about 2 million people. The cities of Albuquerque, New Mexico, and El Paso, Texas, lie within the aquifer system boundaries.

The Rio Grande aquifer system consists of hydraulically interconnected basin-fill aquifers in about 20 alluvial basins extending along the Rio Grande Valley and nearby valleys (Robson and Banta, 1995; Wilkins, 1998). Basin-fill sediments are primarily unconsolidated to moderately consolidated gravel, sand, silt, and clay of Tertiary to Quaternary age. The thickness of basin deposits ranges greatly, from as little as 2,000 feet near El Paso, Texas, to as much as 30,000 feet in the San Luis Valley of southern Colorado (Robson and Banta, 1995). Groundwater in the basin-fill aquifers is generally unconfined, but confining units are present in some basins (Anning and others, 2007). The climate is semiarid to arid, and precipitation in the valleys is mostly lost to evapotranspiration (Robson and Banta, 1995). Recharge occurs along mountain fronts from infiltration of mountain stream runoff and inflow from fractured bedrock (Robson and Banta, 1995; Bexfield and others, 2011; Thiros and others, 2014). Stream loss from the Rio Grande and (or) crop irrigation are also major sources of recharge to some basins (Robson and Banta, 1995; Bexfield and others, 2011). Discharge is dominated by evapotranspiration, particularly for topographically closed basins, although groundwater discharges naturally to the Rio Grande in some areas (Robson and Banta, 1995; Bexfield and others, 2011). In some basins, groundwater withdrawals for irrigation and (or) public supply have become a substantial discharge component, altering groundwater flow directions (Robson and Banta, 1995; Bexfield and others, 2011; Thiros and others, 2014).

Groundwater quality in the

Rio Grande aquifer system was evaluated in 2014 by sampling 60 publicsupply wells that were spatially distributed across the aquifer system. Parts of the region are sparsely populated, and public-supply wells are not evenly distributed. Consequently, the study area was delineated by placing 5-kilometer (3.2-mile) buffers around existing public-supply wells; an equal-area grid was then defined within the buffered area. For this discussion, we define the study area as the depth zone used for public supply in the Rio Grande aquifer system in the buffered area. Water-quality data collected from the spatially distributed wells (6 in Colorado, 45 in New Mexico, and 9 in Texas) are representative of water quality in the study area, following the approach described by Belitz and others (2010). This approach allows for the estimation of the percentage of the study area with concentrations that are high, moderate, and low with respect to constituent benchmarks. The accuracy of the estimates depends on the distribution and number of wells, not the size of the area (Belitz and others, 2010). The wells ranged from 25 to 2,000 feet deep (averaging 643 feet deep) and were open to the aquifer across long depth intervals (averaging about 295 feet). Samples were analyzed for a large number of water-quality constituents derived from natural and human sources.

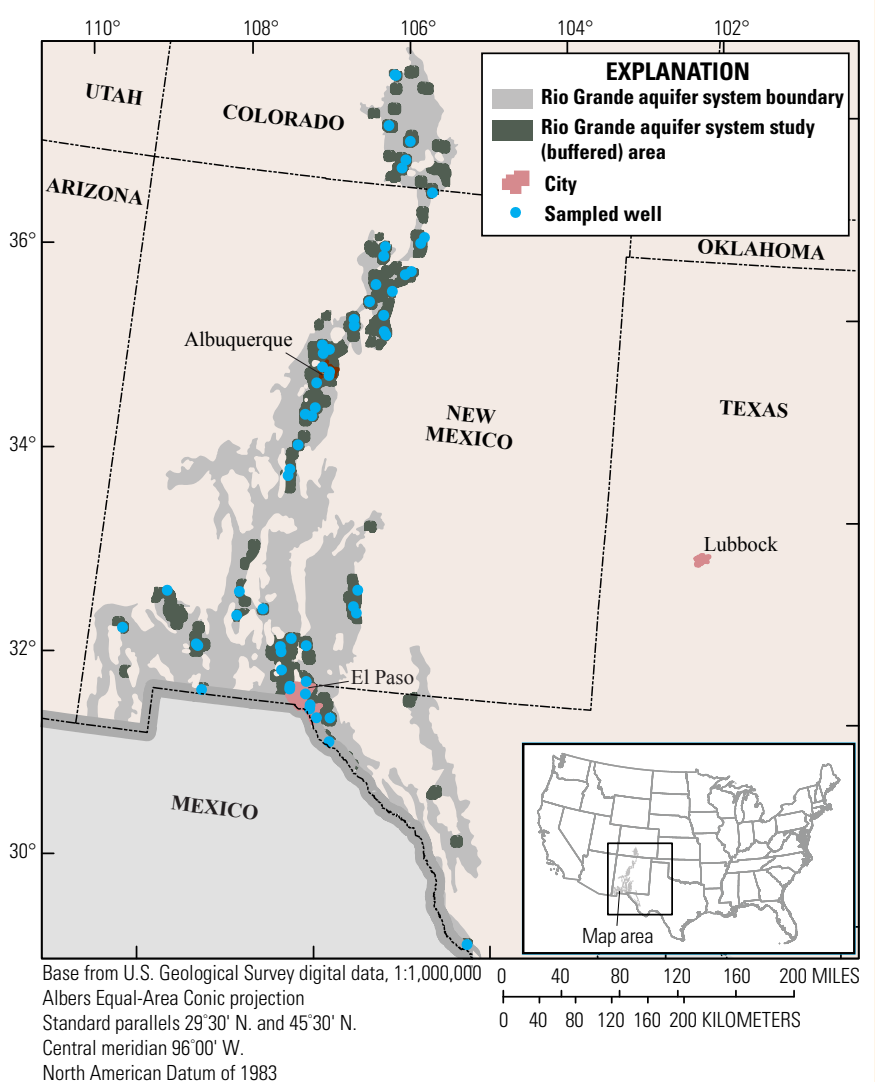

Overview of Water Quality

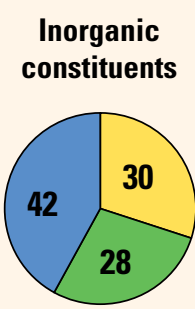

Organic constituents

CONSTITUENT CONCENTRATIONS

\section{High $\bigcirc$ Moderate $\bigcirc$ Low or not detected}

Values are a percentage of the study area with concentrations in the three specified categories. Percentages might not sum to 100 because of rounding.

Principal Aquifer Studies (Burow and Belitz, 2014) are designed to evaluate groundwater used for public supply prior to any treatment. Groundwater quality is assessed by comparing concentrations to benchmarks established for drinking-water quality. Benchmarks and definitions of high, moderate, and low relative concentrations are discussed at the bottom of page 3 . Water from 70 percent of the wells sampled did not have high concentrations of any contaminant measured.

Many inorganic constituents are naturally present in groundwater. The concentrations of inorganic constituents can be affected by natural processes as well as by human activities. One or more inorganic constituents with human-health benchmarks were detected at high concentrations in about 30 percent of the study area and at moderate concentrations in about 28 percent.

Organic constituents derived from human activities are used in household, business, industrial, and agricultural products. They can enter the environment through normal usage, spills, or improper disposal. Organic constituents with human-health benchmarks were not detected at high or moderate concentrations in the study area. 


\section{Results: Groundwater Quality at the Depth Zone Used for Public Supply in the Rio Grande Aquifer System}

\section{INORGANIC CONSTITUENTS}

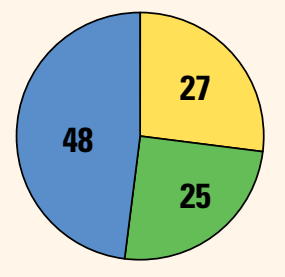

\section{Trace elements and major and minor ions}
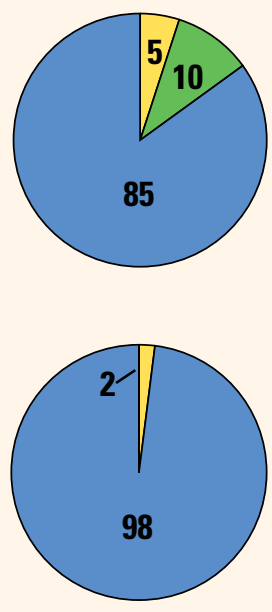

\section{Radioactive constituents}

\section{Nutrients}

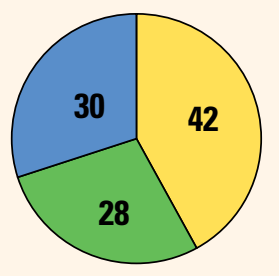

\section{Inorganic Constituents With Human-Health Benchmarks}

Trace elements and major and minor ions are naturally present in the minerals of rocks, soils and sediments, and in the water that comes into contact with those materials. Samples were analyzed for 34 trace elements and major and minor ions, of which 19 have humanhealth benchmarks. Constituents from this group were detected at high concentrations in about 27 percent of the study area (the depth zone used for public supply) and at moderate concentrations in about 25 percent. Arsenic was the trace element most frequently detected at high concentrations (18 percent) and at moderate concentrations ( 22 percent). Fluoride, strontium, and uranium were detected at high concentrations in about 3 percent of the study area and at moderate concentrations in about 8,2 , and 7 percent of the study area, respectively. Manganese and molybdenum were not detected at high concentrations but occurred at moderate concentrations in about 2 and 3 percent of the study area, respectively.

Radioactivity is the release of energy or energetic particles during the spontaneous decay of unstable atoms. Humans are continuously exposed to small amounts of natural radioactivity. Most of the radioactivity in groundwater comes from the decay of isotopes of uranium and thorium that are naturally present in minerals in aquifer materials. Samples were analyzed for eight radioactive constituents, of which four have human-health benchmarks. Radioactive constituents were present at high levels in about 5 percent of the study area (gross-alpha activity and radon) and at moderate levels in about 10 percent of the study area.

Nutrients are naturally present at low concentrations in groundwater; high and moderate concentrations (relative to human-health benchmarks) generally result from human activities. Samples were analyzed for five nutrients, of which two have human-health benchmarks. Common sources of nutrients, aside from soils, include fertilizer applied to crops and landscaping, seepage from septic systems, and human and animal waste. The nutrient nitrate was detected at high concentrations in about 2 percent of the study area; nutrients were not present at moderate concentrations.

\section{Inorganic Constituents and Field Measurements With Non-Health-Based Benchmarks}

(Not included in water-quality overview charts shown on the front page)

Some constituents affect the aesthetic properties of water, such as taste, color, and odor, or can create nuisance problems, such as staining and scaling. The benchmarks used for these constituents were non-regulatory secondary maximum contaminant level (SMCL) benchmarks established for public drinking water. Some constituents, such as manganese and fluoride, have human-health benchmarks and SMCLs. Samples were analyzed for 11 constituents that have SMCLs. One or more of these were present at high concentrations or values relative to the SMCL in about 42 percent of the study area and at moderate concentrations in about 28 percent.

Total dissolved solids (TDS) concentration is a measure of the salinity of the groundwater based primarily on concentrations of ions. All water naturally contains TDS as a result of the weathering and dissolution of minerals in rocks and sediments. Concentrations of TDS can be high because of natural factors or as a result of human activities, such as applications to the land surface of road salt, fertilizers, or other chemicals in urban or agricultural areas. Most of the study area had high (35 percent) or moderate (32 percent) concentrations of TDS. The ions chloride, fluoride, and sulfate were present at high concentrations in about 10,12 , and 7 percent of the study area, respectively, and at moderate concentrations in 8,10 , and 23 percent, respectively.

Anoxic conditions in groundwater (low amounts of dissolved oxygen) can result in the release of iron and manganese in minerals to the groundwater. Manganese was present at high concentrations relative to the SMCL in about 3 percent of the study area. Iron was not present at high concentrations relative to the SMCL. Iron and manganese were both present at moderate concentrations in about 2 percent of the study area. 


\section{Results: Groundwater Quality at the Depth Zone Used for Public Supply in the Rio Grande Aquifer System}

\section{ORGANIC CONSTITUENTS}

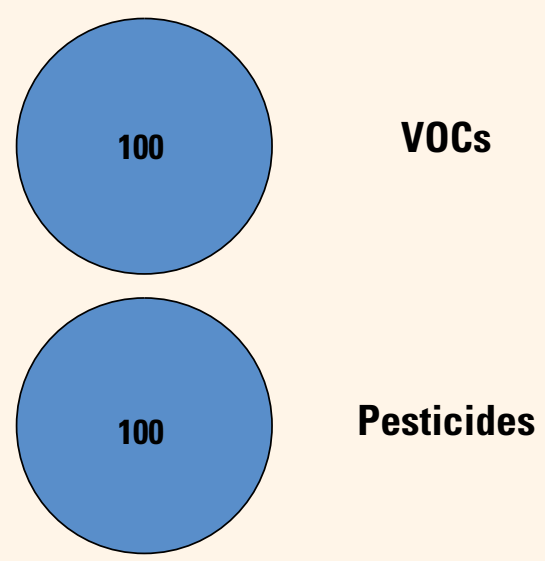

\section{Volatile Organic Compounds With Human-Health Benchmarks}

Volatile organic compounds (VOCs) are present in many household, commercial, industrial, and agricultural products and are characterized by their tendency to volatilize (evaporate). Samples were analyzed for 90 VOCs, of which 38 have human-health benchmarks. No VOCs were detected at high or moderate concentrations in the study area.

\section{Pesticides With Human-Health Benchmarks}

Pesticides, including herbicides, insecticides, and fumigants, are applied to crops, gardens and lawns, around buildings, and along roads to help control unwanted vegetation (weeds), insects, fungi, and other pests. Samples were analyzed for 227 pesticide compounds (pesticides and their breakdown products), of which 119 have human-health benchmarks. Pesticide compounds were not detected at high or moderate concentrations in the study area.

\section{BENCHMARKS FOR EVALUATING GROUNDWATER QUALITY}

The USGS NAWQA Project uses benchmarks established for drinking water to provide context for evaluating the quality of untreated groundwater. The quality of water received by consumers can be different, because after withdrawal, groundwater may be treated prior to delivery. Federal regulatory benchmarks for protecting human health are used for this evaluation of water quality when available. Otherwise, non-regulatory human-health benchmarks and non-regulatory aesthetic benchmarks are used. Not all constituents analyzed have benchmarks and, thus, are not considered in this context. Out of 55 inorganic constituents and properties and 317 organic constituents, 24 and 157, respectively, have human-health benchmarks.

Concentrations are considered high if they are greater than a human-health benchmark (Toccalino and others, 2014) or SMCL. For inorganic constituents, concentrations are moderate if they are greater than one-half of a benchmark. For organic constituents, concentrations are moderate if they are greater than one-tenth of a benchmark; this lower threshold is used because organic constituents are generally less prevalent and have smaller concentrations relative to benchmarks than inorganic constituents (Toccalino and others, 2004).

\section{Benchmark Type and Value for Selected Constituents}

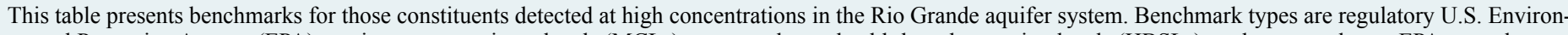

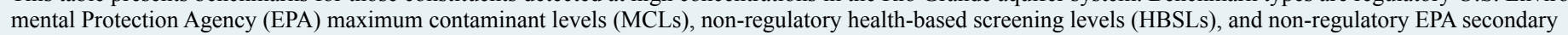
maximum contaminant levels (SMCLs).

[Abbreviations: ppb, part per billion or microgram per liter $(\mu \mathrm{g} / \mathrm{L}) ; \mathrm{ppm}$, part per million or milligram per liter $(\mathrm{mg} / \mathrm{L}) ; \mathrm{pCi} / \mathrm{L}$, picocurie per liter]

\begin{tabular}{|c|c|c|c|c|c|}
\hline \multirow{2}{*}{ Constituent } & \multicolumn{2}{|c|}{ Benchmark } & \multirow{2}{*}{ Constituent } & \multicolumn{2}{|c|}{ Benchmark } \\
\hline & Type & Value & & Type & Value \\
\hline Arsenic & MCL & $10 \mathrm{ppb}$ & Total dissolved solds (TDS) & SMCL & $500 \mathrm{ppm}$ \\
\hline Strontium & HBSL & $4,000 \mathrm{ppb}$ & Fluoride & SMCL & $2 \mathrm{ppm}$ \\
\hline Fluoride & MCL & $4 \mathrm{ppm}$ & Sulfate & SMCL & $250 \mathrm{ppm}$ \\
\hline Uranium & MCL & $30 \mathrm{ppb}$ & Chloride & SMCL & $250 \mathrm{ppm}$ \\
\hline Nitrate as nitrogen & MCL & $10 \mathrm{ppm}$ & Manganese & SMCL & $50 \mathrm{ppb}$ \\
\hline Gross-alpha activity & MCL & $15 \mathrm{pCi} / \mathrm{L}$ & $\mathrm{pH}$ & SMCL & $6.5-8.5$ \\
\hline Radon-222 & HBSL & $4,000 \mathrm{pCi} / \mathrm{L}$ & & & \\
\hline
\end{tabular}




\section{Spatial Distribution of Arsenic Concentrations}

Inorganic constituents with human-health benchmarks were present at high or moderate concentrations in 58 percent of the Rio Grande aquifer system study area. The most prevalent of these inorganic constituents was arsenic, which occurred at high or moderate concentrations in 40 percent of the study area; the distribution, however, varied from north to south. High or moderate concentrations of arsenic were present in 17 percent of the samples collected in the study area in Colorado; the sum of high and moderate concentrations increased to 36 and 34 percent in northern and southern New Mexico, respectively, and was greatest, 78 percent, in Texas. These differences in water quality across the study area might reflect position of rocks and sediments that compose the aquifers, aquifer flow-path characteristics, aquifer geochemical conditions, and other factors (Bexfield and others, 2011). differences in the com-

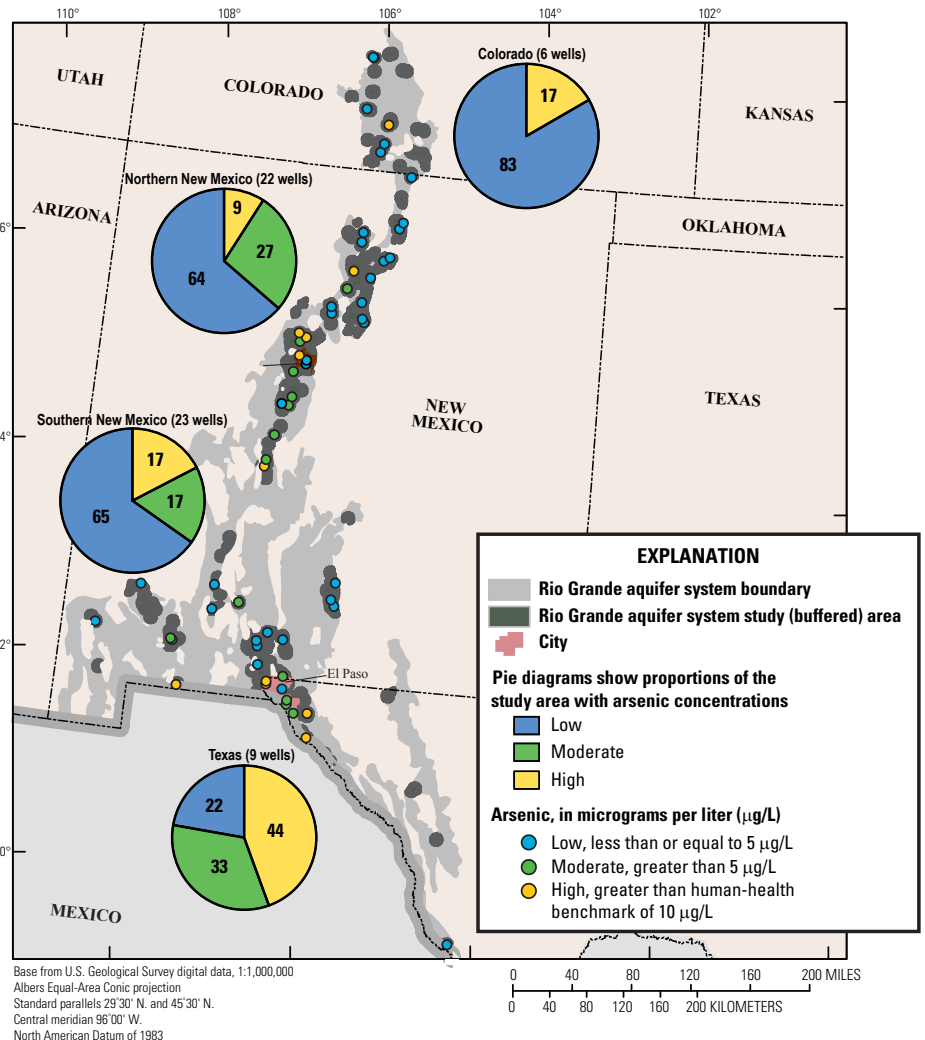

By MaryLynn Musgrove and Laura M. Bexfield

\section{SELECTED REFERENCES}

Anning, D.W., Bauch, N.J., Gerner, S.J., Flynn, M.E., Hamlin, S.N., Moore, S.J., Schaefer, D.H., Anderholm, S.K., and Spangler, L.E., 2007, Dissolved solids in basin-fill aquifers and streams in the southwestern United States (ver. 1.1, March 22, 2010): U.S. Geological Survey Scientific Investigations Report 2006-5315, 168 p., https://pubs.usgs.gov/sir/2006/5315/.

Arnold, T.L., Bexfield, L.M., Musgrove, MaryLynn, Lindsey, B.D., Stackelberg, P.E., Barlow, J.R., DeSimone, L.A., Kulongoski, J.T., Kingsbury, J.A., Ayotte, J.D., Fleming, B.J., and Belitz, Kenneth, 2017a, Groundwater-quality data from the National Water-Quality Assessment Project, January through December 2014 and select quality-control data from May 2012 through December 2014: U.S. Geological Survey Data Series 1063, 83 p., https://doi.org/10.3133/ds1063.

Arnold, T.L., Bexfield, L.M., Musgrove, MaryLynn, Lindsey, B.D., Stackelberg, P.E., Barlow, J.R., DeSimone, L.A., Kulongoski, J.T., Kingsbury, J.A., Ayotte, J.D., Fleming, B.J., and Belitz, Kenneth, 2017b, Datasets from groundwater-quality data from the National Water-Quality Assessment Project, January through December 2014 and select quality-control data from May 2012 through December 2014: U.S. Geological Survey data release, https://doi.org/10.5066/F7W0942N.

Belitz, K., Jurgens, B., Landon, M.K., Fram, M.S., and Johnson, T., 2010, Estimation of aquifer scale proportion using equal area grids-Assessment of regional scale groundwater quality: Water Resources Research., v. 46, no. 11, 14 p., doi:10.1029/2010WR009321.

Bexfield, L.M., Thiros, S.A., Anning, D.W., Huntington, J.M., and McKinney, T.S., 2011, Effects of natural and human factors on groundwater quality of basin-fill aquifers in the southwestern United States-Conceptual models for selected contaminants: U.S. Geological Survey Scientific Investigations Report 2011-5020, 90 p., https://pubs.usgs.gov/sir/2011/5020/.

Burow, K.R., and Belitz, K., 2014, Groundwater studies_-Principal aquifer surveys: U.S. Geological Survey Fact Sheet 2014-3024, 2 p., https://dx.doi.org/10.3133/fs20143024.

DeSimone, L.A., McMahon, P.B., and Rosen, M.R., 2014, The quality of our Nation's waters - Water quality in principal aquifers of the United States, 1991-2010: U.S. Geological Survey Circular 1360, 151 p., https://dx.doi.org/10.3133/cir1360.

Robson, S.G., and Banta, E.R., 1995, Ground water atlas of the United States-Segment 2, Arizona, Colorado, New Mexico, Utah: U.S. Geological Survey Hydrologic Atlas 730-C, https://pubs.usgs.gov/ha/ha730/ch_c/index.html.

Thiros, S.A., Paul, A.P., Bexfield, L.M., and Anning, D.W., 2014, The quality of our Nation's waters; Water quality in basin-fill aquifers of the southwestern United States-Arizona, California, Colorado, Nevada, New Mexico, and Utah, 1993-2009: U.S. Geological Survey Circular 1358, 113 p., https://dx.doi.org/10.3133/cir1358.

Toccalino, P.L., Norman, J.E., Phillips, R.H., Kauffman, L.J., Stackelberg, P.E., Nowell, L.H., Krietzman, S.J., and Post, G.B., 2004, Application of health-based screening levels to ground-water quality data in a state-scale pilot effort: U.S. Geological Survey Scientific Investigations Report 2004-5174, 64 p., https://pubs.usgs.gov/sir/2004/5174/.

Toccalino, P.L., Norman, J.E., and Schoephoester, K.M., 2014, Health-based screening levels for evaluating water-quality data: U.S. Geological Survey webpage, doi:10.5066/F71C1TWP, accessed at https://water.usgs.gov/nawqa/HBSL.

Wilkins, D.W., 1998, Summary of the southwest alluvial basins regional aquifer system in parts of Colorado, New Mexico, and Texas: U.S. Geological Survey Professional Paper 1407-A, 49 p., https://pubs.er.usgs.gov/publication/pp1407A.

\section{Principal Aquifer Studies}

The USGS NAWQA Project has been assessing the quality of groundwater since 1991. The NAWQA studies include Land Use Studies (LUS), Major Aquifer Studies (MAS), and Principal Aquifer Studies (PAS). These three study types are based on sampling networks of wells distributed across an area of interest. The LUS networks typically consist of observation wells that are relatively shallow; MAS networks typically consist of domestic-supply wells that are intermediate in depth; and PAS networks typically consist of public-supply wells that are relatively deep. A national synthesis of shallow and intermediate depth groundwater quality was reported by DeSimone and others (2014). A regional synthesis of water quality for basin-fill aquifers in the southwestern United States, including the Rio Grande aquifer system, was reported by Thiros and others (2014). This Fact Sheet provides a summary of PAS data for 60 public-supply wells sampled in 2014 in the Rio Grande aquifer system (data available in Arnold and others, 2017b).

The PAS assessments like this one allow for the comparison of constituent concentrations in untreated groundwater with benchmarks established for the protection of human health and for aesthetic qualities of drinking water and also provide a basis for comparison of groundwater quality among the principal aquifers.

The data collected by the NAWQA Project include chemical analyses generally not available as part of regulatory compliance monitoring, including measurements at concentrations much lower than the levels used as humanhealth benchmarks, and measurement of constituents that can be used to trace the sources and movement of groundwater.

\section{For more information}

Technical reports and hydrologic data collected for the USGS NAWQA Project may be obtained from:

\section{NAWQA Chief Scientist}

U.S. Geological Survey

12201 Sunrise Valley Drive, MS 413

Reston, VA 20192-0002

Email: nawqapublicinfo@usgs.gov

WEB: https://water.usgs.gov/nawqa/

ISSN 2327-6916 (print)

ISSN 2327-6932 (online)

https://doi.org/10.3133/fs20173047 